\title{
FUND OG FORSKNING
}

I DET KONGELIGE BIBLIOTEKS

SAMLINGER

Bind 46

2007

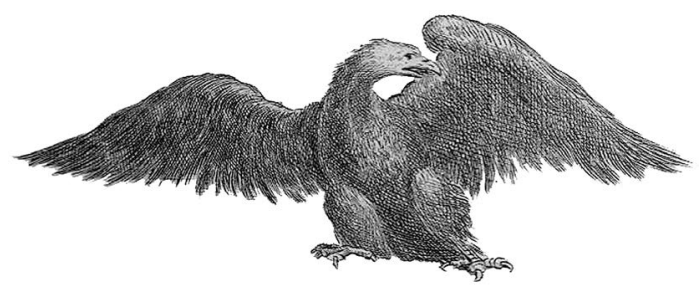

With summaries

KØBENHAVN 2007

UDGIVET AF DET KONGELIGE BIBLIOTEK 
Om billedet på papiromslaget se s. 292.

Det kronede monogram på kartonomslaget er tegnet af

Erik Ellegaard Frederiksen efter et bind fra Frederik III's bibliotek

Om titelvignetten se s. 102.

(C) Forfatterne og Det Kongelige Bibliotek

Redaktion: John T. Lauridsen

Redaktionsråd:

Ivan Boserup, Grethe Jacobsen, Ingrid Fischer Jonge,

Erland Kolding Nielsen, Niels Krabbe,

Stig T. Rasmussen, Marie Vest

Fund og Forskning er et peer-reviewed tidsskrift.

Papir: Munken pure 120 gr.

Dette papir overholder de i ISO 9706:1994

fastsatte krav til langtidsholdbart papir.

Grafisk tilrettelæggelse og nodesats: Jakob K. Meile

Tryk og indbinding: Richard Larsen Grafisk A/S

ISSN 0060-9896

ISBN 978-87-7023-011-7 


\title{
"SAGEN HAR DEN STØRSTE BETYDNING FOR VORT LAND"
}

\author{
H.O. LANGES KAMP FOR ET DANSK
}

ARKÆOLOGISK INSTITUT I ÆGYPTEN

$\mathrm{AF}$

\section{Lars Schreiber Pedersen}

I begyndelsen af august 1938 modtog den danske ægyptolog H.O. Lange et brev fra sin kollega og mangeårige ven, den tysk-jødiske ægyptolog Ludwig Borchardt. Ludwig Borchardt var tidligere direktør for det tyske arkæologiske institut i Egypten, men havde efter sin pensionering oprettet sit eget institut i Kairo, finansieret af en til lejligheden oprettet stiftelse i Schweiz. I brevet berettede Borchardt om den seneste stramning i det nationalsocialistiske Tysklands kurs over for jødiske statsborgere. For at beskytte såvel instituttet i Kairo som sig selv og hustruen Mimi, tilbød Ludwig Borchardt at overdrage instituttet til en videnskabelig institution i Danmark, mod at han og hustruen fik tildelt dansk indfødsret. H.O. Lange forstod vigtigheden af vennens brev og forelagde personligt sagen for udenrigsminister P. Munch. H.O. Lange ønskede dels at hjælpe sin gamle ven ud af hans vanskelige situation, og dels så Lange muligheden for at sikre Danmark et værdifuldt institut i Ægypten, der ville gøre Københavns Universitet til det ægyptologiske centrum i Skandinavien.

$$
* * *
$$

I 1933 indtog den koleriske toldersøn fra Braunau, Adolf Hitler, det tyske Rigskancelli. Det nye Tysklands udenrigspolitiske tone var aggressiv og vakte bekymring overalt i Europa, og inden for Det Tredje Riges grænser gennemførte nazisterne op gennem 1930'erne en racepolitik, der sendte hundredetusinder af mennesker på flugt. Som andre nabolande oplevede også Danmark presset fra flygtningestrømmene. Antallet af flygtninge, der nåede frem til Danmarks grænser, var forholdsvis beskedent, men det afholdt ikke Danmark fra at føre en stram og til tider inhuman flygtningepolitik. De færreste kom gennem nåleøjet. For de jødiske flygtninge var grænsen lukket fra efteråret $1938 .^{1}$

1 Den danske flygtningepolitik 1933-1940 har været genstand for flere undersøgelser de senere år. Se. f.eks. Hans Kirchhoff: Et menneske uden pas er ikke noget menneske: 
Denne artikel handler om en usædvanlig sag, der henover sommeren og efteråret 1938 voldte ministre og embedsmænd i Udenrigs-, Indenrigs- og Undervisningsministeriet ikke så få vanskeligheder. I centrum stod to ældre herrer med et livslangt venskab og et omfattende videnskabeligt virke inden for ægyptologien bag sig: Det Kongelige Biblioteks overbibliotekar 1901-1924, Hans O. Lange og den berømte tyske ægyptolog Ludwig Borchardt.

\section{H.O. Lange som agyptolog}

H.O. Langes betydningsfulde indsats inden for den danske og internationale ægyptologi er velbeskrevet. ${ }^{2}$ Interessen for ægyptologien blev vakt i barndomsårene i Århus, da en klassekammerat viste ham et bind af Ludvig Daaes og A.C. Drolsums illustrerede verdenshistorie, hvori den norske ægyptologiprofessor Jens Lieblein havde skrevet afsnittet om det gamle Ægypten. ${ }^{3}$ Særlig mødet med hieroglyfferne betog den unge skoledreng, som siden brugte hver en ledig stund på at udforske Nillandets kultur og historie.

Som nybagt student begyndte H.O. Lange i 1881 sine universitetsstudier i København. Da ægyptologien var et udsigtsløst studium i jobmæssig henseende, valgte han i stedet - uden nogen større kærlighed til den klassiske oldtid - at studere klassisk filologi. Til held for Langes ægyptologiske studier fik han i 1882 arbejde ved Universitetsbiblioteket og i 1885 fast ansættelse på Det Kongelige Bibliotek, hvorved han blev økonomisk sikret. Ægyptologien kunne han nu - på linie med sine to andre store interesser, det kirkelige menighedsarbejde og det videnskabelige biblioteksstudium - hellige sig i fritiden.

Vendepunktet i H.O. Langes ægyptologiske liv kom i 1887, da han foretog en studierejse til Berlin, hvor professor Adolf Erman og dennes medarbejdere ved Berlins ægyptiske museum netop i disse år var i færd med at revolutionere ægyptologien. Mødet med "den opgaaende Sol paa Ægyptologiens Himmel”, som Lange senere omtalte Er-

Danmark i den internationale flygtningepolitik 1933-1939, 2005 og Lone Rünitz: Af hensyn til konsekvenserne: Danmark og flygtningespørgsmålet 1933-1940, 2005.

${ }^{2}$ Se f.eks. Torben Holm-Rasmussen: H.O. Lange, grundlægger af dansk ægyptologi og "grå eminence" i international ægyptologi, Magasin fra Det Kongelige Bibliotek, 14:4, 1999, s. 39-50 og Wolja Erichsen: H.O. Lange som Ægyptolog, Povl Helweg-Larsen: H.O. Lange: En mindebog, 1955, s. 356-373, som det følgende bygger på.

${ }^{3}$ Jens Lieblein et al: Egyptens, Forasiens og Grakenlands Historie indtil det romerske Herredømmes Tid, Kristiania 1876 (1. udg.). 
Ludwig Borchardt 1931.

Foto: Schweizerisches Institut für Ägyptische Bauforschung und Altertumskunde, Kairo.

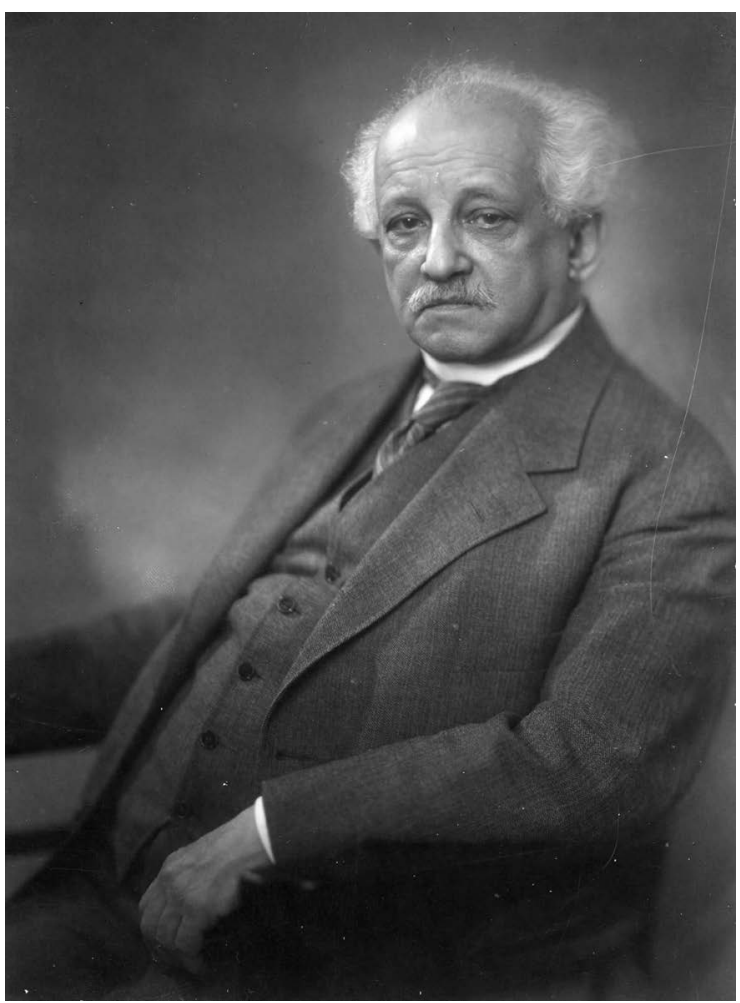

man i et udkast til sine erindringer fra 1939, fik afgørende betydning for Langes videnskabelige udvikling. ${ }^{4}$ Frem til Ermans død i 1937 bestod der et varmt venskab mellem mesteren og eleven. I Berlin lærte H.O. Lange en række medarbejdere fra det spirende forskningsmiljø omkring Adolf Erman at kende, heriblandt Ludwig Borchardt.

\section{Ludwig Borchardt}

Ludwig Borchardt var jævnaldrende med H.O. Lange, begge var de født i 1863. Borchardt var egentlig uddannet arkitekt (Bauingeniör), men på grund af sin store interesse for forhistorisk byggeteknik blev han ansat som videnskabelig medarbejder ved det ægyptiske museum i Berlin under Adolf Ermans ledelse. Det var her, i berlinermuseets papyrussamling, at Borchardt og Lange første gang mødte hinanden. Da de interesserede sig for de samme hieratisk skrevne papyri, slog

${ }^{4}$ Manuskript på KB: NKS 3919, $4^{\circ}$, kps. 6. 
de kræfterne sammen, og samarbejdet førte til et venskab, der skulle vare i mere end et halvt århundrede. ${ }^{5}$ Venskabet og de videnskabelige relationer blev de efterfølgende år plejet gennem en omfattende korrespondance samt under Borchardts besøg i København og H.O. Langes studierejser til Berlin og Kairo.

I 1895 blev Ludwig Borchardt sendt til Ægypten for at registrere og udbedre de skader på templet i Philæ, opførelsen af den første dæmning ved Aswan havde forårsaget. I Berlin havde man også andre tanker med udsendelsen af Borchardt. Adolf Erman ønskede afskrifter af en række tempelindskrifter til sit arbejde med at lave en ordbog over det ægyptiske sprog, og det preussiske udenrigsministerium krævede udførlige beretninger fra den engelske koloni. ${ }^{6}$ I 1899 hentede Ludwig Borchardt på den ægyptiske regerings vegne H.O. Lange til Kairo som medarbejder ved udarbejdelsen af det videnskabelige katalog over Kairomuseets genstande. Sammen med den tyske kollega Heinrich Schäfer blev det Langes opgave at ordne og publicere museets omkring 800 steler fra Det Mellemste Rige. ${ }^{7}$ Lange opholdt sig i Ægypten i næsten et år og havde blandt andet lejlighed til at følge Borchardts udgravning af soltemplet i Abusir.8

I 1907 blev Ludwig Borchardt leder af det nyåbnede "Kaiserlich Deutsche Institut für Ägyptische Altertumskunde" i Kairo. ${ }^{9}$ Året efter blev Borchardt centrum i en større videnskabelig skandale, hvor han blev beskyldt for at have ladet sine udenlandske kollegers arbejde udspionere. I Berlin var Adolf Erman rasende og en række prominente tyske videnskabsmænd krævede Borchardt hjemkaldt, men det preussiske udenrigsministerium holdt en beskyttende hånd over dets meddeler i Kairo. ${ }^{10}$ I årene 1911-1914 ledede han for Det tyske Orientselskab udgravningerne af farao Akhenatons gamle hovedstad ved

\footnotetext{
${ }^{5}$ Erichsen 1955, s. 364.

${ }^{6}$ Norbert Dürring: Nofretete und andere Kleinigkeiten: Ludwig Borchardt und die frühe Ägyptologie, Antike Welt, 31, 4, 2000, s. 424.

7 H.O. Lange: Levnedsberetning til Ordenskapitlet 1907, Magasin fra Det Kongelige Bibliotek, 16:4, 2003, s. 19.

${ }^{8}$ H.O. Lange og hustruen Jonnas rejsedagbog fra rejsen opbevares i Håndskriftsamlingen på Det Kongelige Bibliotek.

${ }^{9}$ Werner Kaiser: 75 Jahre Deutsches Archäologisches Institut Kairo 1907-1982, Mainz 1982, s. 4.

${ }^{10}$ Siegfried Wölffling: Untersuchungen zur Geschichte des Deutschen Instituts für Ägyptische Altertumskunde zu Kairo. Doktorafhandling, Martin-Luther-Universität, Halle-Wittenberg 1960, s. $48 \mathrm{ff}$.
} 
Tel el-Amarna. ${ }^{11}$ Det var under disse udgravninger, at Ludwig Borchardt, i billedhuggeren Tuthmoses værksted, den 6. december 1912 gjorde den opdagelse, der mere end nogen anden blev forbundet med hans navn, nemlig fundet af busten af Akhenatons førstehustru, Nefertiti. ${ }^{12}$

Første Verdenskrig medførte en afbrydelse af instituttets arbejde i Ægypten og bidrog til den stærkt tysknationale Borchardts videnskabelige isolation fra hovedparten af de udenlandske kolleger. Kontakten med Lange blev genoptaget i december 1918. I et brev til vennen i København berettede Borchardt om de fire krigsår:

"Persönlich ist es mir in den vier Jahren nicht besonders schlecht gegangen, nur sind mir für meine eigentliche Arbeit diese vier Jahre völlig gestrichen worden, was in meinem Alter sehr viel bedeutet. Wer weiss, ob ich das werde nachholen können?"13

Der skulle dog gå yderligere fem år, før Ludwig Borchardt atter kunne tiltræde sin gamle direktørstilling i Kairo. Tel el-Amarna kunne han ikke vende tilbage til, da udgravningsrettighederne var overgået til det engelske Egypt Exploration Society. Hertil kom begrænsede økonomiske midler, der kun tillod mindre arkæologiske undersøgelser i årene 1924-1928. ${ }^{14}$ Ludwig Borchardt forlod i januar 1929 direktørposten på grund af alder, men havde på ingen måde tænkt sig at nyde et stille otium. I 1931 grundlagde han sit eget institut i Kairo, der finansieredes af en stiftelse oprettet i Schweiz samme år.

Hitlers magtovertagelse i 1933 betød en brat omvæltning for Ludwig og hustruen Mimis liv i Kairo. I årevis inden det nazistiske styre kom til magten havde det borchardtske hjem været et centrum for den tyske koloni i Kairo, nu levede det ældre jødiske ægtepar et liv i fuldstændig isolation fra den tyske koloni i byen. ${ }^{15}$ Ludwig Borchardts videnskabelige og private kontakter med tyske kolleger blev færre, og yngre tyske ægyptologer, der rejste til Kairo, fik inden afrejsen fra

11 Dürring 2000, s. 426.

12 Om fundet af busten og de efterfølgende stridigheder om ejerskabet se f.eks. Rolf Krauss: 75 Jahre Büste der Nofretete/Nefretiti in Berlin, Jahrbuch Preussischer Kulturbesitz XXIV, 1987, s. 87-124. Busten af Nefertiti befinder sig i dag på Altes Museum i Berlin.

13 Ludwig Borchardt til H.O. Lange 25.12.1918. KB: NKS 3736, $4^{\circ}$, kps. 2.

14 Dürring 2000, s. 426. Borchardt tiltrådte den 31.10.1923.

15 Ludwig Borchardt til H.O. Lange 8.2.1934. KB: NKS 3736, 4 ${ }^{\circ}$ kps. 2. 
Tyskland forbud mod at opsøge ham. ${ }^{16}$ Trængslerne skulle dog blive endnu større.

\section{Kare Lange!}

I starten af august 1938 modtog H.O. Lange et fortroligt brev fra sin gamle ven. I brevet skrev en bekymret Ludwig Borchardt om den seneste stramning i nazistyrets kurs over for jødiske statsborgere, Hermann Görings forordning af 26. april 1938, der betød, at alle tyske jødiske statsborgere i ind- og udland skulle lade deres formue registrere. Ludwig Borchardt frygtede en konfiskation af formuen og havde ikke i sinde at efterleve forordningen. Han frygtede, at beslutningen, når den blev kendt, ville føre til, at han og hustruen ville miste deres tyske statsborgerskab. For at beskytte såvel institutet i Kairo som sig selv og hustruen, var Ludwig Borchardt kommet på den tanke,

"das Institut einer Einrichtung (Universität, Akademie, Museum oder so ähnlich) eines vor den Nazis sicheren Staates, im dem auch für unsere Wissenschaft das nötige Interesse vorhanden ist, zu geben und gleichseitig für meine Frau und mich dessen Staatsangehörigkeit zu erwerben. Meine Frage an Sie ist nun: Ist dies in Ihrem Vaterlande, dessen Bestimmungen über den Erwerb der Staatsangehörigkeit ich nicht kenne, möglich? Sie werden ja sicher genügend Verbindungen mit amtlichen Stellen dort haben, die Ihnen, auch wenn Sie vertraulich, ohne Namensnennung, anfragen und die Sachlage klarstellen, Auskunft geben werden". ${ }^{17}$

Under sin anden rejse til Ægypten i 1929/30 havde H.O. Lange besøgt Ludwig Borchardt og instituttet, der lå i Kairo-bydelen Zamalek. Instituttet holdt til i to store forbundne villaer, og indeholdte blandt andet en genstandssamling og et stort videnskabeligt bibliotek.

Lange forstod vigtigheden af vennens brev, og at der skulle handles hurtigt. Heldigvis havde den tidligere overbibliotekar ved Det Kongelige Bibliotek forbindelserne i orden, som Ludwig Borchardt havde formodet. Den 1. august fremlagde Lange personligt sagen for uden-

\footnotetext{
16 Ludwig Borchardt til H.O. Lange 13.11.1937. KB: NKS 3736, 4 , kps. 2.

17 Ludwig Borchardt til H.O. Lange 30.7.1938. Rigsarkivet (herefter RA): Udenrigsministeriet, j.nr. 41 V 293 (afskrift). Hverken dette eller de følgende breve fra Ludwig og Mimi Borchardt til H.O. Lange eksisterer længere i original.
} 


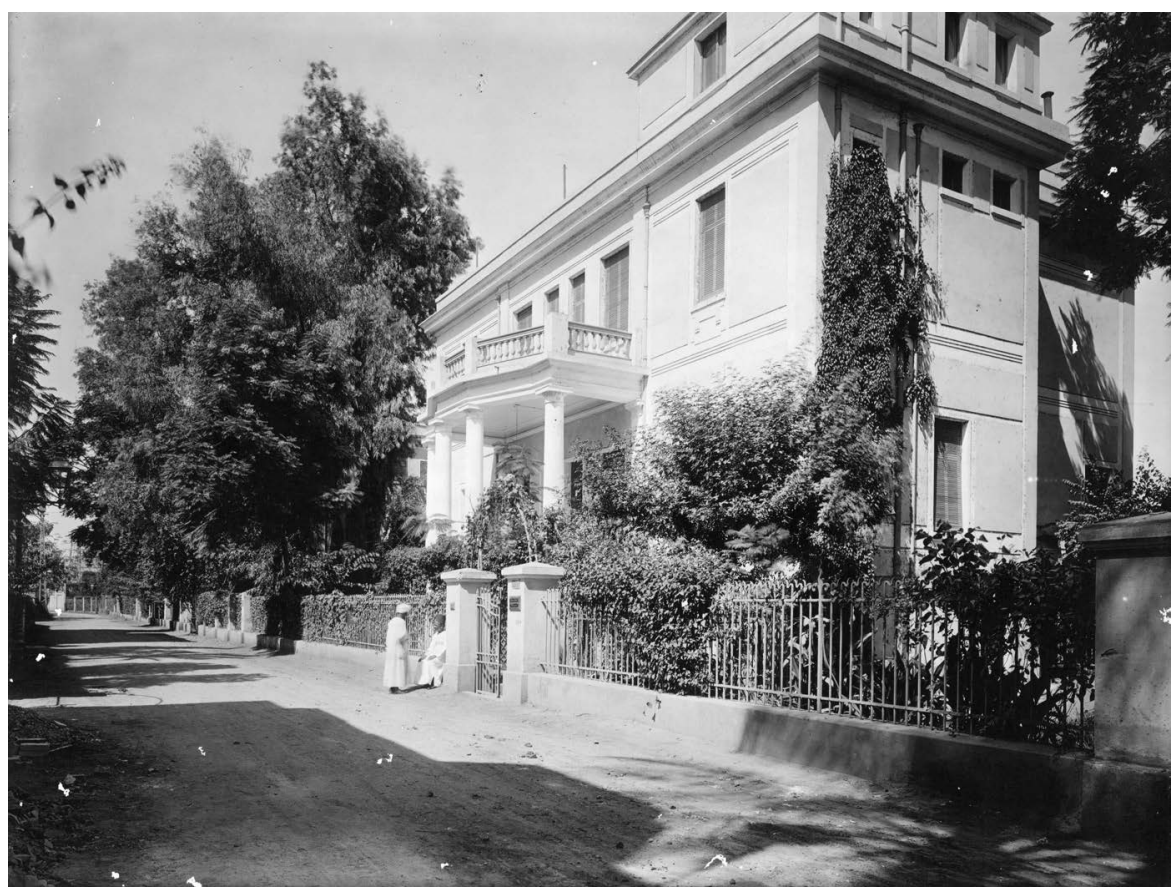

Ludwig Borchardts institut i Kairo-bydelen Zamalek. Bygningen rummede tidligere 'Kaiserlich Deutschen Instituts für Ägyptische Altertumskunde' (idag 'Schweizerisches Institut für Ägyptische Bauforschung und Altertumskunde in Kairo'). Foto: Schweizerisches Institut für Ägyptische Bauforschung und Altertumskunde, Kairo.

rigsminister P. Munch, og dagen efter fulgte en længere redegørelse til Munch om Borchardt og Langes forhold til kollegaen. Lange var ikke i tvivl om tilbuddets betydning:

"Her er Tale om en saa enestaaende Gave, der i høj Grad vil bidrage til at fremhæve og befæste Danmarks Stilling i den internationale Videnskab, at der er al Grund til at søge en Udvej til at opfylde hans Ønske om dansk Statsborgerret. (...) For mig har det været en stor Oplevelse, at dette Tilbud kommer til Danmark. Det sætter Kronen paa de Bestræbelser, som har været Gjenstand for mine stadige Overvejelser og tildels realiserede Planer, at gjøre Kjøbenhavns Universitet til Hovedsædet for det ægyptologiske Studium i Norden og overhovedet i de smaa Lande. Jeg er overbevist om, at Hr. Ministeren fuldt ud forstaar Sagens baade videnskabelige og nationale Betydning, og det 
er mit Haab, at det maa lykkes Dem at overvinde de Vanskeligheder, der maatte stille sig i Vejen for at kunne modtage denne imponerende Gave og derved redde en videnskabelig Institution, der ellers vil være dødsdømt." 18

\section{Indenrigsministeriets modstand}

H.O. Langes brev må have gjort et vist indtryk på P. Munch. Den 4. august anmodede Udenrigsministeriets direktør O.C. Mohr Indenrigsministeriet om en udtalelse om Ludwig og Mimi Borchardts muligheder for at opnå dansk indfødsret. ${ }^{19}$ I Indenrigsministeriet så man ikke de store chancer for dette. Blandt medarbejderne var der forståelse for, at Ludwig og Mimi Borchardt ledte sig efter et nyt fædreland: "Men det ses ikke, hvorfor det netop skal være Danmark. Hans hidtidige Forbindelse med Danmark synes ikke at være af den art, at man selv med meget stor Imødekommenhed kan gaa saa vidt som til at naturalisere ham", som en medarbejder anførte. ${ }^{20}$

Blandt ministeriets embedsmænd var der bred enighed om, at Ludwig Borchardt ikke opfyldte de sædvanlige betingelser for opnåelse af dansk indfødsret. Med sine 74 år overskred Ludwig Borchardt de 70 år, der gjaldt som maksimumalder for naturalisation, og den maksimale indvandringsalder på 50 år. Han talte - det formodede man i hvert fald i ministeriet - ikke et ord dansk og, væsenligst af alt, hans tilknytning til Danmark var ringe og af en sådan art, at den ikke adskilte sig fra, hvad enhver større international videnskabsmand ville have erhvervet sig efter lang tids virksomhed. Om han overhovedet havde i sinde at komme til Danmark, tvivlede man stærkt på. En embedsmand påpegede Ludwig Borchardts hjælp med at sikre Danmark en række videnskabeligt interessante papyri, men mente alligevel ikke, at det var nok: "Denne Interesse er den eneste spinkle Traad, hvori Sagen hænger, og den er for spinkel. Den viser, at Ansøgeren har haft nogen Føling med danske Forhold, men absolut ikke af den Art, hvormed vi plejer at begrunde Indfødsret". ${ }^{21}$ Ludwig Borchardt havde faktisk siden århundredeskiftet hjulpet danske institutioner,

18 H.O. Lange til P. Munch 2.8.1938. RA: Udenrigsministeriet, j.nr. 41 V 293.

19 O.C. Mohr til Indenrigsministeriet 4.8.1938. RA: Indenrigsministeriet, 2. kontor, j.nr. 62-1023/1938.

${ }^{20}$ Notat af 8.8.1938. RA: Indenrigsministeriet, 2. kontor, j.nr. 62-1023/1938.

${ }^{21}$ Notat af 9.8.1938. RA: Indenrigsministeriet, 2. kontor, j.nr. 62-1023/1938. 
med Ny Carlsberg Glyptotek i spidsen, med opkøb af ægyptiske oldsager, men det vidste man tilsyneladende ikke i ministeriet.

En spinkel mulighed eksisterede dog. Hvis Ludwig Borchardt var villig til at forære institut og den under stiftelsen hørende formue til den danske stat, ville han måske have større chance for at opnå sit mål. Ingen i ministeriet troede dog på, at Ludwig Borchardt reelt havde til hensigt at forlægge bopæl og institut til Danmark. Forespørgslen tjente udelukkende Borchardts ønske om at bevare institutet og den tilhørende formue. Eller sagt med en af embedsmændenes egne ord: "Saalænge han selv staar som Ejeren, smager den eventuelle danske Naturalisation for meget af 'film'."22

For embedsmændene i Indenrigsministeriet spillede hverken ansøgernes jødiske baggrund eller frygten for at fremprovokere en stærk tysk reaktion - som hos kollegerne i Udenrigsministeriet - nogen væsentlig rolle. Ludwig og Mimi Borchardt opfyldte ikke kravene for at opnå dansk indfødsret, så simpelt var det. En tildeling af indfødsret ville skade ministeriets omdømme, da det for omverdenen ville se ud som om, dansk indfødsret var til salg for penge. Ludwig og Mimi Borchardt kunne under ingen omstændigheder opnå dansk indfødsret, hvilket blev meddelt Udenrigsministeriet.

\section{Udenrigsministeriets kvaler}

Den 11. august 1938 blev Ludwig Borchardts henvendelse diskuteret på et ministermøde, hvor det blev besluttet at lade udenrigs-, indenrigs- og undervisningsministeren iværksætte en nærmere undersøgelse af sagen. ${ }^{23}$ Samme dag modtog Lange et nyt brev fra Ludwig Borchardt, hvori den tyske ægyptolog berettede om sin fortvivlede situation. Borchardts frygt gjaldt de igangværende forhandlinger mellem Ægypten og Tyskland om den tyske konsularjurisdiktion i Ægypten. En amerikansk kollega havde rådet Ludwig Borchardt til så hurtigt som muligt at finde en løsning på indfødsretspørgsmålet, hvorfor Borchardt måtte afvise Langes forslag om at søge at opnå dansk statsborgerskab ved indfødsretsloven i marts 1939. Borchardt foreslog i stedet Lange den mulighed, at han og hustruen Mimi blev ansat som medarbejdere ved det kommende danske institut og fik tildelt dansk

${ }^{22}$ Notat af 8.8.1938. RA: Indenrigsministeriet, 2. kontor, j.nr. 62-1023/1938.

23 Tage Kaarsted (udg.): Ministermødeprotokol 1933-40. Ministeriet Stauning-Munch, 1984, s. 241. 
statsborgerskab på dagen for instituttets overdragelse til den danske stat. ${ }^{24}$ Lange foreslog i sit svar til vennen samme dag en anden løsningsmodel:

"Vor der Aufgabe des Vermögens haben Sie das Institut der Universität geschenkt, können dann die Nazis mit Hilfe der Ägypter die Häuser rauben? Sie können Sie natürlich staatslos machen aber was mehr? Sie werden so schnell als möglich Direktor des dann dänischen Instituts, das unter dänischem Schutz steht, und Sie als Direktor wird wohl einige Zeit staatslos sein, aber in einigen Monaten werden Sie dänischer Staatsbürger, Ja, verzeihen Sie mir, ich sehe ja alles von aussen an, aber wäre das Institut dann nicht gerettet?" ${ }^{25}$

Lange modtog aldrig et svar fra kollegaen. Den 12. august døde Ludwig Borchardt i Paris efter at være blevet syg under en togrejse fra Zürich. Borchardt var på vej til London, hvor han skulle mødes med den amerikanske gesandt og diskutere mulighederne for at erhverve sig amerikansk statsborgerskab.

Hustruen Mimi Borchardt slog dog i et brev til H.O. Lange fast, at tilbuddet til Danmark fortsat stod ved magt. I breve til såvel den radikale indenrigsminister Bertel Dahlgaard som udenrigsminister P. Munch foreslog Lange nu en ny løsningsmodel for institutsagen. Mimi Borchardt skulle skænke institut og stiftelse til Københavns Universitet. Stiftelsens kapital skulle anbringes i Danmark, mens Mimi Borchardt forblev i Kairo som administrator for instituttets bygninger og daglige drift. Som administrator af dansk statsejendom skulle hun nu uden vanskeligheder kunne tildeles dansk indfødsret, mente Lange. Men det hastede med en afgørelse, hvis instituttet skulle komme på danske hænder. Foruden USA havde Ludwig og Mimi Borchardt også følere ude i England - nærmere bestemt til universitetet i Oxford. Tanken om at instituttet kunne glide Danmark af hænde, pinte Lange: "Den Tanke, at Englænderne muligvis finder Udvej til at naturalisere Fru Borchardt, inden vore Overvejelser er tilende, kan

24 Afskrift af Ludwig Borchardts brev til H.O. Lange er gengivet i et brev fra H.O. Lange til P. Munch 11.8.1938. RA: Udenrigsministeriet, j.nr. 41 V 293.

25 Afskrift af H.O. Langes svar til Ludwig Borchardt 11.8.1938 er gengivet i et brev fra H.O. Lange til P. Munch 11.8.1938. RA: Udenrigsministeriet, j.nr. 41 V 293. Lange skrev to breve til P. Munch den 11.8. 
jo ikke andet end pine. Vi fik Tilbudet først, og for os vil det betyde uendelig meget mere end for England". ${ }^{26}$

Fem dage senere uddybede han sine tanker i et brev til udenrigsminister P. Munch:

"Hun [Mimi Borchardt, LSP] udsteder snarest et retsgyldigt Gavebrev, hvorved Instituttet (Husene i Kairo med Bibliothek osv) og Stiftelsen (den rørlige Formue, der er bestemt til Instituttets Drift) overdrages til Kjøbenhavns Universitet som et nordisk Institut; den rørlige Formue anbringes enten i Danmark eller i England. Den faste Ejendom er da dansk Statsejendom, og som saadan vil den ikke kunne røres af Tyskland. Fru Borchardt vil da uden Tvivl miste sin tyske Borgerret og blive Statsløs for en Tid. Hun maa have et fast Tilsagn om dansk Indfødsret til Marts og maa komme herop for personlig at ordne Forholdet og faa den fornødne juridiske Bistand.”

Lange sluttede sit brev til udenrigsministeren med atter at pointere sagens store betydning:

"Hr. Ministeren vil sikkert undskylde, at jeg bliver at presse paa med denne Sag. Jeg føler mig stærkt forpligtet overfor Videnskaben og Universitet og ikke mindre overfor min gamle Ven. Naar jeg tænker paa de Muligheder, som et saadant Institut under vort Universitet, aabner, saa tænker jeg ikke mindst paa, at derved vil Danmarks Stilling som Forgangsland i Norden i den ægyptologiske Forskning yderligere befæstes. (...) Sagen har den største Betydning for vort Land”. ${ }^{27}$

For embedsmændene i Udenrigsministeriet voldte sagen kvaler. I et notat opstillede en af ministeriets embedsmænd de mange problemer. En gnidningsløs overtagelse af instituttet vanskeliggjordes af den "Verordnung über die Anmeldung des Vermögens von Juden," som Hermann Göring havde udstedt den 26. april 1938, samt af en tilstødende gennemførelsesforordning af 18. juni 1938. I følge forordningerne havde Borchardt som 'ikke-arisk' tysk statsborger pligt til at anmelde sin samlede formue over for Berlins politipræsident

${ }^{26}$ H.O. Lange til Bertel Dahlgaard 15.8.1938. RA: Indenrigsministeriet, 2. kontor, j.nr. 62-1023/1938. Lange sendte samme dag et brev med tilsvarende indhold til P. Munch.

27 H.O. Lange til P. Munch 20.8.1938. RA: Udenrigsministeriet, j.nr. 41 V 293. 
inden 31. oktober 1938. Enhver forandring i formuen efter forordningens ikrafttræden skulle ligeledes indberettes. Forordningens $§ 7$ tillagde herefter kommissæren for den tyske fire års-plan, Hermann Göring, en beføjelse til at sikre, at formuen blev nyttiggjort i overensstemmelse med den tyske økonomis interesser. Formuen kunne med andre ord blive konfiskeret uden mulighed for erstatning. Såfremt Ludwig Borchardt først fik dansk statsborgerskab, og overdragelsen af instituttet fandt sted, efter at han havde oversiddet anmeldelsesfristen, ville han kunne rammes af straf- og konfiskationsbestemmelsen i forordningens $\S 8 .{ }^{28}$

Spørgsmålet var dernæst, om en tildeling af dansk statsborgerskab inden anmeldelsesfristens udløb ville have virkning, som om Borchardt havde haft dansk indfødsret allerede ved forordningens ikraftræden. Det vurderede notatets forfatter ikke som sandsynligt, men foreslog, at man eventuelt kunne hente fortrolige oplysninger fra gesandtskabet i Berlin.

Fulgte man endelig Langes forslag om en tidsmæssig adskillelse af spørgsmålet om tildeling af statsborgerskab og overdragelsen af instituttet for at få den virkeliggjort inden 31. oktober, ville Borchardt stadigvæk have pligt til at anmelde formueovergangen. Gjorde han ikke det, ville han kunne straffes efter forordningens $\S 8$. Opfyldte han pligten, ville han eventuelt kunne straffes for fors $\varnothing g$ på overtrædelse af forordningens $\S 7$. For sagens videre forløb fandt notatets bagmand det vigtigt at få afklaret, hvorvidt der fandtes retshjælpsaftaler mellem Tyskland og Ægypten, men selv om sådanne fandtes, fandt han det ikke forsvarligt at tage imod tilbuddet:

"I det store og hele kan man vel sige, at en Overdragelse som den foreslaaede strider mod Aanden i den Gøringske Forordning, navnlig dens $\S 7$, eller med andre Ord, at en Overdragelse, hvad enten den sker isoleret eller $i$ Forbindelse med en - $i$ alle Tilfalde ekstraordinar - erhvervelse af dansk Indfødsret, og hvad enten der findes Retshjælpsaftaler mellem Tyskland og Ægypten eller ikke, fra tysk Side vil blive betragtet som en Omgaaelse." ${ }^{29}$

28 Forfatteren til notatet, der er dateret 17.8.1938, har ikke været bekendt med, at Ludwig Borchardt fem dage tidligere var afgået ved døden.

${ }^{29}$ Notat af 17.8.1938. RA: Udenrigsministeriet, j.nr. 41 V 293. 
Spørgsmålet om eksistensen af retshjælpsaftaler mellem Tyskland og Ægypten sendte Udenrigsministeriet den 13. august videre til gesandtskabet i Kairo. ${ }^{30}$ Lederen af Udenrigsministeriets juridisk-politiske afdeling, Bent Falkenstjerne, bad efterfølgende kollegerne i Indenrigsministeriet om at stille sagen i bero, indtil svaret fra Kairo forelå. ${ }^{31}$

I Udenrigsministeriet var holdningen i slutningen af august den, at Mimi Borchardt nødvendigvis måtte bosætte sig i Danmark, men at den efterfølgende overdragelse af institut og formue, hvis det overhovedet var muligt, kunne give hende en særlig fortrinlig stilling i forhold til opnåelsen af dansk statsborgerskab. Den holdning delte embedsmændene i Indenrigsministeriet ikke. En tildeling af dansk indfødsret kunne fortsat ikke komme på tale. I første omgang fulgte man dog henstillingen fra Udenrigsministeriet og satte i stedet sin lid til, at en forestående tysk-ægyptisk retshjælpstraktat ville umuliggøre en overførsel af instituttet. ${ }^{32}$

\section{Universitetets skepsis}

I Undervisningsministeriet, der allerede i begyndelsen af august var blevet underrettet om sagen, mente man ikke, at den göringske forordning udgjorde nogen reel trussel mod instituttet i Kairo. Den pålagde blot jødiske formuer i ind- og udland en række fiskale bånd, som en embedsmand udtrykte det. Københavns Universitet skulle dog høres om, hvorvidt det var interesseret i at modtage gaven. At svaret ville blive et ja, var man ikke i tvivl om. Når bekræftelsen fra universitetet forelå, kunne undervisningsminister Jørgen Jørgensen drøfte sagen med P. Munch og Bertel Dahlgaard på et ministermøde. ${ }^{33}$

Universitetet behandlede Ludwig Borchardts tilbud på et forretningsudvalgsmøde i universitetets konsistorium den 3. september 1938, hvor sagkundskaben inden for det filosofiske fakultet, heriblandt H.O. Lange, var indkaldt for at drøfte sagen. Mødet forløb ikke, som H.O. Lange havde håbet. Blandt de tilstedeværende var der bekymring for, om universitetet kunne magte opgaven, og om sagen ville skade forholdet til tysk videnskab. Efter at universitetets rektor,

30 Bent Falkenstjerne til Det Kgl. Gesandtskab i Kairo 13.8.1938. RA: Udenrigsministeriet, j.nr. 42 V 293.

31 Notat af 24.8.1938. RA: Indenrigsministeriet, 2. kontor, j.nr. 62-1023/1938.

32 Notat af 31.8.1938. RA: Indenrigsministeriet, 2. kontor, j.nr. 62-1023/1938.

33 Notat af 12.8.1938. RA: Undervisningsministeriet, j.nr. 2200/1938. 
C.E. Bloch, havde afsluttet mødet, greb Lange ordet og udtalte sin skuffelse over en del af de under mødet faldne udtalelser, idet han frygtede, at sagen nu ville strande. Udtalelserne på mødet havde dog også fået Lange til at tvivle på, hvorvidt universitetet var i stand til at løfte opgaven. ${ }^{34}$ Men H.O. Lange vidste samtidig, at det kun ville være et spørgsmål om tid, inden egnede kandidater ville melde sig på banen. Igennem sit virke som lektor i ægyptologi ved Københavns Universitet i årene 1924-1937 havde H.O. Lange selv stået for uddannelsen af en ny og talentfuld generation af danske ægyptologer, som på sigt ville kunne varetage ledelsen af et dansk institut i Kairo.

At Lange havde god grund til at være bekymret, viste det svar, C.E. Bloch sendte til Undervisningsministeriet den 9. september. Rektorens største bekymring var, at institutsagen skulle skade forholdet mellem universitetet og den tyske videnskab. Universitetet var, i følge Bloch, ikke i stand til at bedømme, om modtagelsen af gaven fra et politisk synspunkt var uden betænkeligheder og ønskede derfor ikke at tage stilling til den side af sagen. Han ønskede ikke at udtale sig om det økonomiske grundlag for en overtagelse af instituttet og erklærede sig uden nærmere kendskab til de retslige forhold, der bestod i forhold til den af Ludwig Borchardt efterladte formue. At gaven var af stor videnskabelig værdi betvivlede Bloch ikke, men han pointerede - med rette - at den danske ægyptologi ikke rådede over en fagligt egnet autoritet, der kunne lede et dansk ægyptologisk institut i Ægypten. Flere spørgsmål skulle besvares, inden universitetet kunne tage endelig stilling til sagen, men samlet set var Blochs begejstring til at tage og føle på. ${ }^{35}$

Den 13. september holdt H.O. Lange et møde med departementchef Frederik Graae i Undervisningsministeriet, hvor rektor Blochs holdning til sagen uden tvivl var på dagsordenen. På mødet har Graae formentlig ytret et ønske om et personligt møde med sagens hovedperson, Mimi Borchardt. Dagen efter meddelte Lange nemlig Graae i et brev, at han nu havde skrevet til Mimi Borchardt og bedt hende komme til Danmark og føre forhandlinger om instituttets fremtid. Når Mimi Borchardt kom til København, ville det nye instituts statutter kunne udarbejdes, håbede Lange. Han vurderede, at ledelsen

34 H.O. Lange til C.E. Bloch 4.9.1938. RA: Københavns Universitet, Rektoratet, j.nr. $321 / 1938$.

35 C.E. Bloch til Undervisningsministeriet 9.9.1938. RA: Undervisningsministeriet, j.nr. 2200/1938. 
af instituttet i første omgang ville være i gode hænder hos Ludwig Borchardts assistent, Herbert Ricke, som med tiden ville kunne uddanne en dansk efterfølger. Lange tolkede rektor Blochs udtalelser under forretningsudvalgsmødet den 3. september således, at universitetet i princippet sagde ja til gaven, men at det afventede yderligere oplysninger på visse væsentlige punkter. Rektor Blochs frygt for, at forholdet mellem universitetet og den tyske videnskab kunne komme i fare, hvis man tog imod gaven, fik nogle vel optimistiske kommentarer med på vejen fra den tidligere overbibliotekar: "Forholdet til tysk Videnskab beror paa Realiteter og ikke paa Sindsstemninger. Det vil sikkert blive forstaaet af alle tænkende Forskere, at Institutets Overdragelse til Danmark har reddet for den internationale Videnskab en Institution, der ellers vilde gaa tabt." 36

Hjemvendt fra en udlandsrejse tilsluttede universitetets kurator, M.I.K. Korsgaard, sig i slutningen af september Blochs erklæring, både hvad angik de udenrigspolitiske hensyn og spørgsmålet om hvorledes universitetet rent videnskabeligt skulle lede instituttet. Ud fra økonomiske og administrative hensyn så Korsgaard dog ingen hindringer for, at universitetet overtog driften af instituttet. En nødvendig forudsætning for at modtage gaven var dog, at renterne af den modtagne pengegave var tilstrækkelige til at dække driften af institutet. Kuratoren ønskede den betingelse knyttet til gavens modtagelse, at den efterladte formue - inden gavens modtagelse og inden Mimi Borchardts krav om indfødsret blev opfyldt - skulle deponeres og båndlægges i Universitetskvæsturen. Skete det, så han ingen økonomiske betænkeligheder ved sagen. ${ }^{37}$

Sagen lå nu hos departementschef Frederik Graae, som afventede en samtale med Mimi Borchardt. Ministeriet mente ikke at kunne foretage sig mere i sagen, før den atter var blevet forelagt Udenrigsministeriet. Hvorvidt forholdet til det nationalsocialistiske Tyskland gjorde det tilrådeligt at modtage det borchardtske tilbud eller ej, så embedsmændene i Undervisningsministeriet sig nemlig ikke i stand til at afgøre..$^{38}$

${ }^{36}$ H.O. Lange til Frederik Graae 14.9.1938. RA: Undervisningsministeriet, j.nr. $2200 / 1938$.

37 M.I.K. Korsgaard til Undervisningsministeriet 29.9.1938. RA: Undervisningsministeriet, j.nr. 2200/1938.

38 Notat af 30.9.1938. RA: Undervisningsministeriet, j.nr. 2200/1938. 


\section{Svar fra Kairo}

I Udenrigsministeriet ventede man fortsat på svar fra gesandtskabet i Kairo. Det indløb først i begyndelsen af oktober. Gesandtskabet fandt ingen grund til nævneværdig bekymring. ${ }^{39}$ Ved tysk lov af 25 . februar $1938 \mathrm{og}$ en efterfølgende forordning af 23. maj var tysk og østrigsk konsularjurisdiktion i Agypten ophævet med virkning fra 15. oktober 1937. Tyske konsuler var dog fortsat kompetente i retssager og inden for en række forhold vedrørende person-, familie- og arveret.

I følge forordningen af 23. maj omfattede de tyske konsulers kompetence blandt andet tyske og østrigske statsborgeres overdragelse af gaver. Formelt set hørte sagen ind under tysk konsularjurisdiktion, men om tyskerne i forbindelse med en overdragelse af instituttet til den danske stat så også ville kræve den bragt ind for en tysk afgørelse, var et åbent spørgsmål. En embedsmand i Udenrigsministeriet anså det ikke umiddelbart for sandsynligt. Alligevel så han en eventuel gennmførelse af transaktionen som en omgåelse af tysk lovgivning, hvorfor Danmark, i følge embedsmanden, kun kunne modtage gaven uden en omgående tildeling af dansk statsborgerskab til Mimi Borchardt og med de tyske myndigheders accept. ${ }^{40}$

En fuldmægtig fra ministeriets juridisk-politiske afdelings 1 . kontor (sager af politisk og social karakter), Rolf Kiær, var på bølgelængde med kollegaen:

"Jeg vil derfor henstille, at man kun akcepterer Tilbudet, saafremt det sker i Form af en Gave uden nogetsomhelst Vederlag, og at man endda inden Akcepten forhører sig, hvorledes de tyske Myndigheder ser paa Sagen. Gør vi ikke det sidste, risikerer vi efter Gavens Fuldbyrdelse at blive mødt med Indsigelser fra tysk Side. Hvis en forespørgsel i Berlin fra vor Side bliver besvaret benægtende, har vi i hvert Fald opført os fair overfor Tyskerne, men jeg tror, at vi vilde vinde mere ved den Agtelse for Danmark, der som en Konsekvens af en saadan Holdning dog kan opstaa i tyske Kredse, end ved den videnskabelige og kulturelle Gevinst for Danmark, der med en vis Ret fra tysk Side vil kunne betegnes som Rov". ${ }^{41}$

39 Julius Quedens til Udenrigsministeriet 25.9.1938. RA: Udenrigsministeriet, j.nr. 42 V 293. Julius Quedens var vicekonsul i Kairo 1922-1954/55.

${ }^{40}$ Notat af 6.10.1938. RA: Udenrigsministeriet, j.nr. 42 V 293.

41 Rolf Kiærs notat af 13.10.1938. RA: Udenrigsministeriet, j.nr. 42 V 293. 
Med de nye oplysninger var der nu tilvejebragt tilstrækkelig med materiale, til at en endelig afgørelse af sagen kunne træffes, vurderede Bent Falkenstjerne. Afgørelsen skulle dog ikke træffes af Udenrigsministeriet, men af de rette ressorter: Undervisnings- og Indenrigsministeriet. Inden sagen blev oversendt til Undervisningsministeriet mente Falkenstjerne dog, at man af praktiske grunde skulle forhøre sig, om, hvorvidt Mimi Borchardt ville opretholde gavetilsagnet, selv om hun ikke kunne blive dansk statsborger før nogle år efter hendes tilflytning til Danmark. Hvad Mimi Borchardts svar på en sådan forespørgsel ville blive, var han ikke tvivl om:

"Praktisk talt vil Sagen vistnok hermed være sluttet, idet jeg knapt tror, at Fru Borchardt akcepterer en saadan Udskydelse i Fremtiden af Indfødsretsspørgsmålet. Skulde hun mod Forventning indgaa herpaa, mener jeg, at Um. overfor Ressortministeriet bør anbefale, at de tyske Myndigheder sonderes af opportunistiske Hensyn; jeg kan derimod ikke hidse mig op til særlig Forargelse, saafremt vi eventuelt modtog en udenfor Tyskland beliggende Ejendom som Gave, hvilken Ejendom Tyskerne af Racehensyn søger at unddrage Ejeren”. ${ }^{2}$

Få dage senere diskuterede Falkenstjerne påny sagen med kontorchef J.L. Saurbrey fra Indenrigsministeriets 3. kontor. Saurbrey erklærede det fortsat for udelukket at tildele Mimi Borchardt dansk statsborgerskab til marts 1939. Han var dog villig til at skære det gældende krav for naturalisation af tyske statsborgere - at den pågældende havde opholdt sig i Danmark i 15 år - ned til fem år og muligvis, i betragtning af de særlige omstændigheder, yderligere ned til to-tre år. ${ }^{43}$

\section{Lange gør et nyt fors $\phi g$}

Indenrigsministeriets vilkår for at tildele Mimi Borhardt dansk indfødsret blev overbragt H.O. Lange af Udenrigsministeriets direktør O.C. Mohr. Meddelelsen var endnu et tilbageslag, men Lange lod sig ikke slå ud og udtænkte straks en ny løsningsmodel, som han præsenterede for udenrigsminister $P$. Munch den 28. oktober. Lange mente at vide, at udlændinge, der blev ansat i den danske stats tjeneste, for eksempel som professorer ved universitetet, kunne få dansk indfødsret

42 Bent Falkenstjernes notat af 14.10.1938. RA: Udenrigsministeriet, j.nr. 42 V 293.

43 Bent Falkenstjernes notat af 18.10.1938. RA: Udenrigsministeriet, j.nr. 42 V 293. 


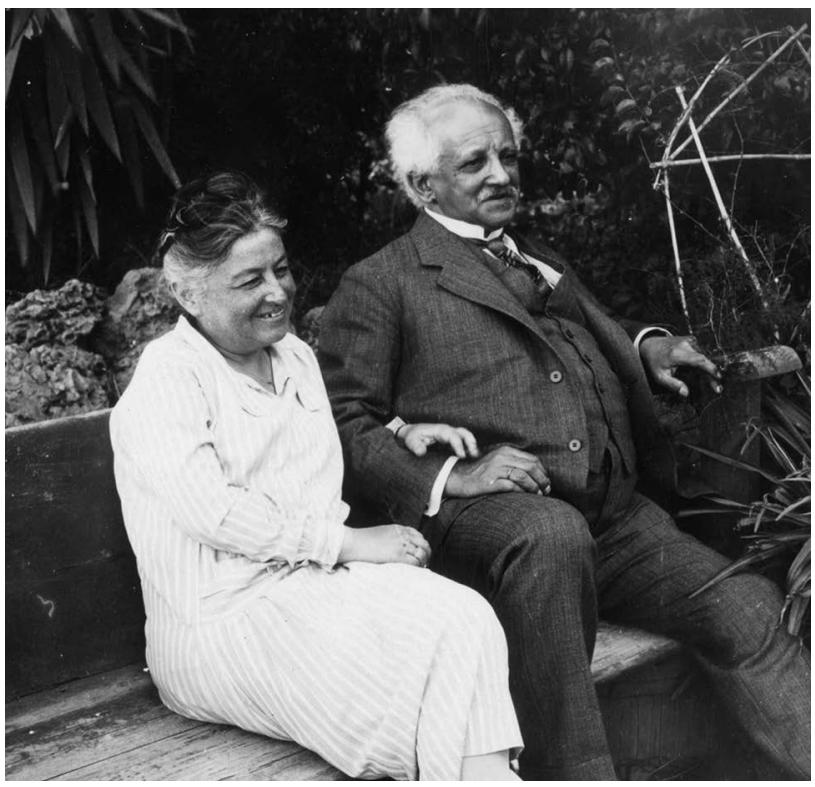

Ludwig og Mimi

Borchardt 1929.

Foto: Schweizerisches Institut für Ägyptische Bauforschung und Altertumskunde, Kairo.

ved den næstkommende indfødsretslov. Blev Mimi Borchardt ansat som administrator for det kommende danske institut og gjort til medlem af instituttets bestyrelse, ville hun, i følge Lange, være i den danske stats tjeneste, og der ville derfor intet være i vejen for at tildele hende indfødsret ved loven i marts 1939. Formuen, foreslog Lange overdraget til stiftelsen i Schweiz, hvorfra Mimi Borchardt kunne modtage en årlig apanage. ${ }^{44}$

H.O. Langes løsningsforslag kunne dog ikke gennemføres. Langes antagelse, at en udlænding ansat i den danske stats tjeneste kunne få dansk statsborgerskab ved førstkommende indfødsretslov, var ikke rigtig og skyldtes sandsynligvis en misforståelse af reglerne om konstitution, som en embedsmand i Udenrigsministeriet påpegede. ${ }^{45}$ Hertil kom, at placeringen af den under instituttet hørende stiftelse i

${ }^{44}$ H.O. Lange til P. Munch 28.10.1938. RA: Udenrigsministeriet, j.nr. 42 V 293. Stiftelsens formue var oprindelig på 500.000 schweizerfranc. Før sin død forhøjede Ludwig Borchardt den, og efter Mimi Borchardts død ville formuen, ifølge Ludwig Borchardt, blive "mehrfach vergrössert". Omregnet til nutidskroner svarer de 500.000 schweizerfranc til ca. 15 mio. kroner.

${ }^{45}$ Notat af 7.11.1938. RA: Udenrigsministeriet, j.nr. 42 V 293. Embedsmænd skulle ifølge Grundloven have dansk indfødsret. Udlændinge, der blev ansat i den danske stats tjeneste, fik ikke automatisk dansk indfødsret ved den førstkommende indføds- 
Schweiz ikke bragte instituttet udenfor tysk konsularjurisdiktion. Udenrigsministeriet fastholdt, at sagen reelt hørte under Undervisningsministeriet, hvorunder et kommende dansk institut sandsynligvis ville komme til at sortere, og Indenrigsministeriet.

I midten af december oversendte Udenrigsministeriet sagen til Undervisningsministeriet. I en følgeskrivelse slog Udenrigsministeriets direktør O.C. Mohr fast, at ministeriet anså en overdragelse af instituttet foretaget af Mimi Borchardt for en omgåelse af tysk lovgivning. Bedømmelsen af en eventuel overdragelse hørte under tysk konsularjurisdiktion i Ægypten, og overdragelsen ville næppe blive godkendt fra tysk side, navnlig ikke når der til overdragelsen blev tilknyttet et krav om dansk indfødsret. Udenrigsministeriet agtede herefter ikke at foretage sig yderligere i sagen. ${ }^{46}$

I midten af december havde H.O. Lange endnu ikke modtaget nogen respons på sit brev til Udenrigsministeriet fra den 28. oktober. Den 21. december henvendte Lange sig derfor atter til P. Munch for at høre nyt om sagens gang. Lange var fortsat i kontakt med Mimi Borchardt, der længtes efter et endeligt svar fra Danmark. Hun var dog stadigvæk villig til at komme til Danmark, når et tilsagn om dansk indfødsret var givet hende. Lange antog fortsat, at spørgsmålet kunne løses på den af ham i brevet fra 28. oktober foreslåede måde, men han fornemmede, at udenrigspolitiske hensyn - Lange tænkte naturligvis på forholdet til Tyskland - stod i vejen for modtagelsen af gaven. ${ }^{47}$

H.O. Langes henvendelse sendte Udenrigsministeriet til videre behandling i Undervisningsministeriet. Her var man fuldt på linie med Udenrigsministeriets vurderinger i sagen. Før man lod sagen falde endeligt til jorden, ønskede ministeriet dog sagen gjort til genstand for forhandlinger mellem undervisnings-, udenrigs- og eventuelt indenrigsministeren. ${ }^{48}$ På et møde i begyndelsen af januar 1939 drøftede udenrigsminister P. Munch sagen med undervisningsminister Jørgen Jørgensen. Resultatet af forhandlingerne blev, at det borchardtske tilbud ikke kunne accepteres. ${ }^{49}$ Beslutningen blev meddelt H.O. Lange i et brev fra Undervisningsministeriet den 20. januar. Begrundelsen

retslov, men måtte nøjes med at være konstitueret i embedet, indtil vedkommende opnåede dansk indfødsret.

46 O.C. Mohr til Undervisningsministeriet 19.12.1938. RA: Undervisningsministeriet, j.nr. 2200/1938.

47 H.O. Lange til P. Munch 21.12.1938. RA: Udenrigsministeriet, j.nr. 42 V 293.

48 Notat af 22.12.1938. RA: Undervisningsministeriet, j.nr. 2200/1938.

49 Notat af 7.1.1939. RA: Undervisningsministeriet, j.nr. 2200/1938. 
for afslaget angav man som Indenrigsministeriets manglende vilje til at tildele Mimi Borchardt dansk indfødsret ved indfødsretsloven i marts $1939 .{ }^{50}$ Hermed var sagen - og ikke mindst H.O. Langes ihærdige anstrengelser for at sikre Danmark et arkæologisk institut i Ægypten - nået til vejs ende.

\section{Betankeligheder i Kairo}

Hvorledes H.O. Langes bestræbelser for at sikre instituttet blev vurderet af Ludwig og Mimi Borchardt, ved vi kun lidt om. To breve fra september 1938 mellem Mimi Borchardt og Herbert Ricke vidner dog om, at man så på indsatsen med en vis skepsis. Navnlig H.O. Langes motiver var genstand for mistro. Efter at have modtaget et brev fra H.O. Lange skrev Mimi Borchardt den 19. september til Herbert Ricke: "Es ist natürlich, dass man keine Katze im Sack kaufen will, mir scheint aber doch vieles, was er schreibt - na sagen wir gelinde - etwas kleinlich" ${ }^{51}$ Herbert Ricke, der modtog H.O. Langes svarbrev fra Mimi Borchardt til gennemlæsning, udtrykte sig endnu tydligere:

"Der Gesamtendruck ist nicht gerade grosszügig, und man hat vor allem das Gefühl, dass Lange das Institut mit Haut und Haaren fressen will und dann nach eigenen Ideen umändern will. Er ist Philologe und deshalb ist ihm die Bauforschung natürlich ziemlich gleichgültig wenn nicht lästig. (...) Lange will natürlich nur Dänen in das Institut setzen. Das ist begreiflich, aber nicht im Sinne des Mudirs. (...) Etwas peinlich wirkt Langes Zudringlichkeit. Er will gleich ein Haus verkaufen, er will nordische (natürlich nur nordische) Ägyptologen einquartieren. (...) Im ganzen habe ich den Eindruck, dass Lange nicht so sehr das Institut retten will, sondern dass er ein 'grossartiges Geschenk' haben will; der Appetit darauf schimmert überall durch". ${ }^{52}$

\footnotetext{
${ }^{50}$ Frederik Graae til Udenrigsministeriet 20.1.1939. RA: Udenrigsministeriet, j.nr. 42 V 293. De udenrigspolitiske betænkeligheder blev næunt i et udkast, men var fjernet i det endelige brev.

${ }^{51}$ Mimi Borchardt til Herbert Ricke 19.9.1938. Archiv des Schweizerischen Instituts für Ägyptische Bauforschung und Altertumskunde, Kairo.

${ }^{52}$ Herbert Ricke til Mimi Borchardt 23.9.1938. Sst. Jeg takker direktøren for Schweizerisches Institut für Ägyptische Bauforschung und Altertumskunde i Kairo, Dr. Cornelius von Pilgrim, for at have fremskaffet de to breve fra instituttets arkiv.
} 
Ricke havde naturligvis sin stilling som leder af instituttet i tankerne. Reelt havde han, som vi har set, ingen grund til at frygte en dansk overtagelse af instituttet. Foruden de få ægyptologer fandtes i Danmark flere dygtige klassiske arkæologer og arkæologisk skolede arkitekter, der kunne foretage videnskabelige undersøgelser i instituttet. Men ingen var egnede til posten som leder af et dansk institut i Ægypten. Lange selv var ikke arkæologisk skolet og med sine 75 år for gammel, hvorfor han under samtalen med Frederik Graae den 13. september også havde anbefalet Herbert Ricke som leder af et kommende dansk institut.

\section{Alternativerne Harvard og Oxford}

Som næunt var Danmark ikke det eneste land, Ludwig og Mimi Borchardt tog kontakt til. I et brev til den engelske ægyptolog Norman de Garis Davies den 1. august 1938 skrev Ludwig Borchardt, at instituttets eneste redning var at stille det under en mægtig stats beskyttelse. Vel at mærke en stat, der stod uden for Det Tredje Riges indflydelse.

Schweiz, hvor Ludwig og Mimi Borchardt hvert år tilbragte sommermånederne, og hvor instituttets stiftelse var placeret, var ikke på tale. At få et schweizisk pas var så godt som umuligt, og Ludwig Borchardt tvivlede desuden på (med urette skulle det senere vise sig), at landet ville kunne modstå et muligt pres fra det nazistiske Tyskland.

Tre lande og tre universiteter var på tale: USA (Harvard), England (Oxford) og Danmark (København). ${ }^{53}$ At Danmark var at finde blandt valgmulighederne kan umiddelbart undre, da landet hverken var mægtigt eller fri for tysk indflydelse. En væsentlig grund var naturligvis Ludwig Borchardts venskab med H.O. Lange, men mindst lige så væsentligt var det, at Danmark i Københavns Universitet og Ny Carlsberg Glyptotek havde et par velrenommerede ægyptologiske institutioner. Endelig var Danmarks neutralitet under Den Første Verdenskrig givetvis heller ikke uden betydning for den stærkt tysknationale Ludwig Borchardt.

USA og universitetet i Harvard stod dog øverst på Borchardts ønskeliste. Som mellemmand til de amerikanske myndigheder fungerede en gammel bekendt af Borchardt, Harvardprofessoren George A.

53 Ludwig Borchardt til Norman de Garis Davies 1.8.1938 (AHG/42.34.19). Alan H. Gardiner MSS, Sackler Library, Oxford. Efterfølgende blot Gardiner MSS. 
Reisner. ${ }^{54}$ Reisner havde i 1920'erne stået ved Ludwig Borchardts side i kampen for at få frigivet det tyske arkæologiske institut i Kairo, der var blevet beslaglagt under Den Første Verdenskrig. I første omgang ønskede Ludwig Borchardt en midlertidig tilknytning, indtil normale tilstande atter herskede i Tyskland.

Det stod dog hurtigt klart, at amerikanerne ikke ville gå ind på det. I løbet af sommeren må det være gået op for Ludwig Borchardt, at et amerikansk statsborgerskab havde lange udsigter, og han vendte sig derfor mod alternativerne i England og Danmark uden dog at opgive Harvard-planerne. Da Ludwig Borchardt døde i Paris den 12. august 1938 var han således på vej til et møde med den amerikanske ambassadør i London. Mimi Borchardt fortsatte forhandlingerne med amerikanerne frem til september 1938, uden at hendes anstrengelser bar frugt.

I England blev det først og fremmest Oxfordægyptologen Alan H. Gardiner og Norman de Garis Davies, der fra august 1938 talte Ludwig og senere Mimi Borchardts sag over for de britiske myndigheder. I England var situationen omtrent den samme som i Danmark. Sammenlignet med de danske immigrationsregler var de engelske krav en anelse mildere, men Mimi Borchardt kunne ikke opfylde dem. For at opnå britisk statsborgerskab krævedes det dels, at ansøgeren i mindst fire år havde haft bopæl på britisk territorium og desuden havde opholdt sig fast på britisk territorium det seneste år, inden statsborgerskabet blev tildelt. Som i Danmark var det britiske indenrigsministerium ikke villig til at slække på kravene. ${ }^{55}$ Et forsøg på at tildele Mimi Borchardt et såkaldt Nansenpas, en ordning egentlig tiltænkt statsløse flygtninge, led skibbrud i oktober 1938. Den eneste tilbageværende mulighed var nu i følge de britiske myndigheder, at Mimi Borchardt tog ophold på Cypern og søgte om engelsk statsborgerskab derfra eller alternativt søgte om ægyptisk statsborgerskab, hvorved instituttet i det mindste kunne reddes fra tyskerne. ${ }^{56}$

Hvorvidt det nazistiske styre i sommeren 1938 havde til hensigt at beslaglægge instituttet i Kairo får stå hen. Noget tyder dog på, at en beslaglæggelse ikke var nært forestående. I august-september 1938

\footnotetext{
54 George Andrew Reisner (1867-1942) var professor i Ægyptologi ved universitetet i Harvard 1914-1942.

${ }^{55}$ Stephen Gaselee (Foreign Ministry) til Alan H. Gardiner 24.9.1938 (AHG/42.34.5). Gardiner MSS.

${ }^{56}$ Stephen Gaselee til Alan H. Gardiner 26.10.1938 (AHG/42.34.2). Gardiner MSS.
} 
fremviste Mimi Borchardts ægyptiske advokat Ludwig Borchardts testamente på det tyske konsulat i Kairo og vurderede efterfølgende, at der ingen fare var for konfiskation. ${ }^{57}$ For en sikkerheds skyld havde Mimi Borchardt i ugerne efter ægtemandens død i al hemmelighed overdraget instituttet i Kairo til stiftelsen i Schweiz. Overdragelsen var dog udelukkende tænkt som en midlertidig løsning, forsikrede hun Norman de Garis Davies. Schweiz spillede nemlig, i følge Mimi Borchardt, ikke nogen nævneværdig rolle i den ægyptologiske videnskab, og hendes chance for at opnå schweizisk statsborgerskab var lig nul. ${ }^{58}$

I december 1938 meddelte Mimi Borchardt Alan H. Gardiner, at instituttet ikke længere var i umiddelbar fare, da den tyske konsul havde mistet sin juridiske bemyndigelse i Ægypten. ${ }^{59}$

I foråret 1939 videreførtes instituttets videnskabelige arbejde, blandt andet i form af udgravninger ved Karnak, under ledelse af den nye leder Herbert Ricke. Instituttet var nu schweizisk ejendom, men Mimi Borchardt ønskede fortsat tilknytning til en britisk institution. I juni 1939 foreslog hun derfor at mødes med Alan H. Gardiner i slutningen af september for at drøfte instituttets fremtid. ${ }^{60}$ Mødet blev aldrig til noget. Den Anden Verdenskrigs udbrud med Hitlers angreb på Polen den 1. september 1939 forhindrede det.

Ved krigsudbruddet opholdt Mimi Borchardt sig i Schweiz. En tilbagevenden til Ægypten var umulig, da hun som tysk statsborger uden tvivl ville være blevet interneret. Sammen med Herbert Ricke opholdt Mimi Borchardt sig i Schweiz under hele krigen. Instituttets bygninger i Kairo blev vedligeholdt af venner og bekendte og led ingen skade under krigen. Efter krigen blev instituttet kortvarigt beslaglagt af englænderne som formodet tysk ejendom, men efter en ihærdig indsats af flere schweiziske ægyptologer og det schweiziske gesandtskab i Kairo blev det atter frigivet. I 1949/50 åbnede instituttet dørene påny, nu som det officielle schweiziske arkæologiske institut i Ægypten. ${ }^{61}$ Genåbningen af instituttet deltog Mimi Borchardt ikke i. Hun døde i Schweiz i 1948.

\footnotetext{
57 Stephen Gaselee til Alan H. Gardiner 24.9.1938 (AHG/42.34.5). Gardiner MSS. ${ }_{58}$ Mimi Borchardt til Norman de Garis Davies 24.8.1938 (AHG/42.34.11). Gardiner MSS.

${ }^{59}$ Mimi Borchardt til Alan H. Gardiner 28.12.1938 (AHG/42.33.11). Gardiner MSS.

${ }^{60}$ Mimi Borchardt til Alan H. Gardiner 6.7.1939 (AHG/42.33.9). Gardiner MSS.

61 Venligst meddelt forfatteren af direktøren for Schweizerisches Institut für Ägyptische Bauforschung und Altertumskunde i Kairo, Dr. Cornelius von Pilgrim 12.9. 2006.
} 


\section{Afslutning}

Ludwig Borchardts arkæologiske institut i Kairo gled H.O. Lange og Danmark af hænde. H.O. Lange ofrede megen tid og mange kræfter på sagen. Dels ønskede han at hjælpe det ældre jødiske ægtepar ud af deres vanskelige situation, og dels så han muligheden for at sikre Danmark et værdifuldt institut i Ægypten, der ville gøre Københavns Universitet til det ægyptologiske centrum i Skandinavien, ja måske ligefrem blandt alle de mindre lande i verden. Hvilket motiv, der vejede tungest, hvis man overhovedet kan skille dem ad, får stå hen. Men at H.O. Lange gerne havde gjort Frankrig og Tyskland, der på den tid var de eneste lande med egne institutter i Ægypten, selskab, kan der ikke herske tvivl om. Afgørelsen var imidlertid ikke H.O. Langes. Den blev truffet på højeste politiske niveau.

Embedsmændenes store problem var, at sagen hørte under tysk konsularjurisdiktion i Ægypten. For at bringe forholdet udenfor tysk jurisdiktionsbestemmelse måtte man tildele Ludwig og Mimi Borchardt dansk indfødsret, inden en overdragelse af instituttet fandt sted. Det ville ikke være en overtrædelse, men dog en klar omgåelse af tysk lovgivning. Flere embedsmænd i Udenrigsministeriet mente, at sagen kunne ordnes uden en tysk reaktion, men man ville stå bedst, hvis man på forhånd forhørte sig om den tyske stilling til sagen. Ministeriet forhørte sig dog aldrig om sagen i Berlin, men lod det blive ved formodningen om, at tyskerne ville protestere mod en dansk overtagelse af instituttet. En konfrontation med den nationalsocialistiske nabo mod syd på baggrund af en sag, der involverede en omgåelse af tysk lovgivning, ønskede Udenrigsministeriet ikke.

Det egentlige ressortministerium, Undervisningsministeriet, delte Udenrigsministeriets bekymring for, at en overtagelse af instituttet kunne skade forholdet til Tyskland. Den egentlige gavemodtager, Københavns Universitet, var heller ikke ovenud begejstret for tilbuddet. Universitetet erkendte gavens videnskabelige værdi, men frygtede først og fremmest at transaktionen ville skade forholdet til den tyske videnskab. Hertil kom de faglige betænkeligheder ved ikke at kunne mønstre en kvalificeret dansk leder af instituttet.

Sagen stod og faldt i sidste ende med holdningen i Indenrigsministeriet. Her var man, i en tid hvor Danmark oplevede stigende pres fra jødiske flygtninge på sine grænser, ikke villige til at dispensere fra reglerne for tildeling af dansk indfødsret. Dansk indfødsret var ikke til salg for penge. Frygten for at ministeriets omdømme ville 
lide alvorlig skade, hvis transaktionen blev gennemført, var udbredt blandt ministeriets embedsmænd. Det danske indenrigsministerium var ikke ene om at afvise kravet om indfødsret. Ludwig og Mimi Borchardts forhandlinger med USA og England strandede også. I disse lande var man heller ikke villige til at slække på reglerne for tildeling af statsborgerskab mod at få instituttet i Kairo som gave.

H.O. Langes betydning for dansk ægyptologi var enorm, men at skaffe sin videnskab og Danmark et institut i Ægypten formåede han trods ihærdige anstrengelser ikke. Den manglende politiske vilje til at sikre Danmark instituttet i Kairo har uden tvivl skuffet H.O. Lange. Lange døde i 1943 og oplevede dermed ikke sagens endelige afslutning markeret ved åbningen af det schweiziske institut i 1949/50. Siden åbningen har instituttet været samlingspunktet for den schweiziske ægyptologi.

\section{SUMMARY}

Lars Schreiber Pedersen: "This Matter is of the Greatest Importance to Our Country". H.O. Lange's campaign for a Danish archaeological institute in Egypt.

In early 1938, the Danish Egyptologist H.O. Lange received a letter from his colleague and friend of many years, the German-Jewish Egyptologist Ludwig Borchardt. Ludwig Borchardt was the former Director of the German Archaeological Institute in Egypt, but following his retirement had set up his own institute in Cairo, financed by a Swiss foundation established for the purpose. In his letter Borchardt wrote about the latest clampdowns on Jewish citizens in Nazi Germany, which meant that all Jewish German citizens in Germany and abroad had to have their property registered. Ludwig Borchardt feared that his property would be confiscated and did not intend to comply with the decree. He was worried that his decision, when it became known, would result in him and his wife losing their German citizenship. In order to protect the institute in Cairo, as well as himself and his wife, Mimi, Ludwig Borchardt offered to transfer the institute to an academic institution in Denmark in return for Danish citizenship for himself and his wife.

H.O. Lange understood the importance of his friend's letter and put the matter personally to Foreign Minister P. Munch. H.O. Lange wanted to help his old friend - he had known Ludwig Borchardt for more than half a century - out of his difficult situation, but he also saw an opportunity to acquire for Denmark a valuable institute in Egypt that would put the University of Copenhagen at the centre of Egyptology in Scandinavia. During the summer and autumn of 1938 , ministers and officials at the 
Ministry of Foreign Affairs, Ministry of the Interior and Ministry of Education discussed the possibility of acceding to the German-Jewish couple's wishes and securing the academically important institute for Denmark.

In the end it all came to nothing because of the Ministry of the Interior's unwillingness to dispense with current regulations and grant Mimi Borchardt Danish citizenship in the next Nationality Act in March 1939 (in the meantime Ludwig Borchardt had died on 12 August 1938). But there was also reluctance of the part of the Ministry of Foreign Affairs and the Ministry of Education. Acquisition of the institute by Denmark might be perceived in Germany as a deliberate evasion of German law. The University of Copenhagen, which the institute would have come under, recognised the institute's academic value, but feared that the matter might damage the relationship between Danish and German academia. No one wanted a confrontation with Denmark's Nazi neighbour in the autumn of 1938.

Denmark was not the only country to be approached by Ludwig and Mimi Borchardt. The couple had also put out feelers in the USA (Harvard) and Britain (Oxford), but these countries were not willing to relax their citizenship rules in return for being made a gift of the institute in Cairo either.

Nazi Germany never did lay claim to the institute in Cairo, which Mimi Borchardt secretly made over to the Swiss foundation a few weeks after Ludwig Borchardt's death for safety's sake. After the end of World War II the institute reopened its doors in 1949/50 as the Swiss Archaeological Institute in Egypt. Neither H.O. Lange nor Mimi Borchardt lived to see the opening, however. H.O. Lange died in 1943, Mimi Borchardt in 1948. 